\title{
Adalimumab w terapii nieinfekcyjnych stanów zapalnych błony naczyniowej
}

\author{
Adalimumab therapy of noninfectious uveitis
}

Julia Kręcicka' , Anna Turno-Kręcicka ${ }^{2}$, Marta Misiuk-Hojło ${ }^{2}$

${ }^{1}$ Klinika Okulistyki, Uniwersytecki Szpital Kliniczny we Wrocławiu ${ }^{2}$ Katedra i Klinika Okulistyki Uniwersytetu Medycznego we Wrocławiu Kierownik: prof. dr hab. n. med. Marta Misiuk-Hojło

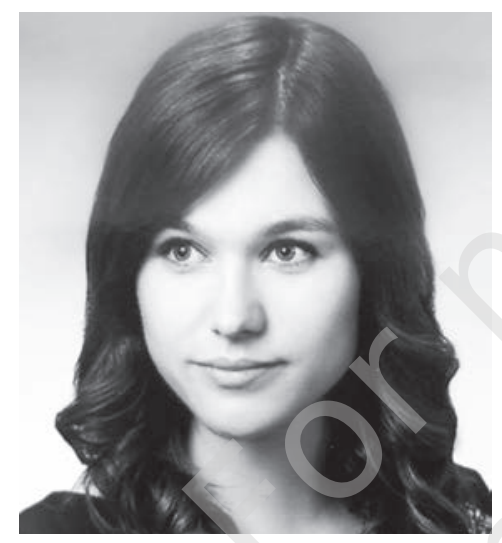

N A JW A ŻN I EJSZE Artykuł przedstawia charakterystykę i działanie adalimumabu - leku biologicznego wprowadzonego do leczenia zapalenia błony naczyniowej części pośredniej i tylnej, a także zapalenia wszystkich części błony naczyniowej.

H I G H L I G H T S The article presents characteristics and activity profile of adalimumab biological medication in treating intermediate, posterior and panuveitis.

\section{STRESZCZENIE}

Nieinfekcyjne zapalenia błony naczyniowej (NZBN) stanowią problem diagnostyczny i terapeutyczny, mają przewlekły i kumulacyjny charakter, a także są przyczyną znaczącej utraty funkcji wzroku u młodych osób, uniemożliwiającej aktywność zawodową. Diagnostyka i leczenie wymagają współpracy specjalistów z różnych dziedzin i opierają się na licznych badaniach laboratoryjnych i obrazowych. Praca przedstawia wskazania, efektywność i bezpieczeństwo terapii pierwszym lekiem biologicznym stosowanym w okulistyce, jakim jest inhibitor czynnika martwicy guza $\alpha$, adalimumab. Może być on uznany za istotną opcję terapeutyczną w leczeniu zapalenia błony naczyniowej części pośredniej i tylnej, a także zapalenia wszystkich części błony naczyniowej, ponieważ pozwala pacjentom na osiągnięcie i utrzymanie długotrwałej kontroli nad chorobą przy jednoczesnej terapii glikokortykosteroidami czy lekami immunomodulującymi lub jej braku.

Słowa kluczowe: terapia biologiczna, nieinfekcyjne zapalenie błony naczyniowej, inhibitory anty-TNF- $\alpha$, adalimumab

\section{ABSTRACT}

Noninfectious uveitis is known for its chronic and cumulative nature. It is often associated with diagnostic and therapeutic difficulties. It causes significant vision loss in young patients, making them incapable of maintaining an active work life. Diagnosis and treatment require cooperation between different specialists and are based on multiple blood tests and other diagnostic tests. This article presents medical indications and the safety and efficacy of adalimumab, a tumor necrosis factor inhibitor and the first biological drug used in ophthalmology. Adalimumab is an important therapeutic option for the treatment of intermediate, posterior, and pan-uveitis, enabling patients to obtain and maintain long-term disease control during simultaneous corticosteroid/immunomodulatory therapy or without it.

Key words: biological therapy, non-infectious uveitis, TNF- $\alpha$ inhibitors, adalimumab 


\section{WSTĘP}

Nieinfekcyjne zapalenia błony naczyniowej (NZBN) sa wyrazem reakcji autoimmunologicznych skierowanych przeciwko antygenom tkanek oka. Ze względu na wczesny początek i przewlekły lub nawrotowy przebieg mogą powodować znaczne upośledzenie funkcji wzroku, negatywnie wpływać na jakość życia i uniemożliwiać aktywność zawodową. Ciężkie postacie NZBN i ich powikłania odpowiadają za 50\% trwałego obniżenia ostrości wzroku i za 10\% ślepoty w krajach Europy i Ameryki Północnej [1]. Wynika to z kumulacyjnego charakteru uszkodzeń struktur oka w NZBN, a także z często opóźnionego i nieefektywnego leczenia.

\section{ROZPOZNANIE I WYBÓR METODY LECZENIA}

Podstawowym warunkiem podjęcia objawowej terapii przeciwzapalnej jest wykluczenie etiologii infekcyjnej stanu zapalnego błony naczyniowej. Diagnostyka różnicowa powinna też obejmować zespoły maskujące, ze szczególnym uwzględnieniem ryzyka chłoniaka wewnątrzgałkowego u osób w starszym wieku.

Metody terapeutyczne w NZBN powinny być dobierane indywidualnie, w zależności od: klinicznego charakteru i ciężkości zapalenia, wieku pacjenta, chorób towarzyszących, efektywności i powikłań dotychczasowego leczenia, ryzyka rozwoju działań niepożądanych oraz gotowości pacjenta do współpracy, przestrzegania zaleceń i regularnych kontroli. Niektóre postacie NZBN o przewlekłym przebiegu, najczęściej jednostronne, będące wynikiem reakcji autoimmunologicznej na antygeny wirusa różyczki, objawiają się jako tzw. zespół heterochromii Fuchsa, który nie wymaga ogólnego leczenia przeciwzapalnego.

Strategia postępowania w ciężkich postaciach NZBN opiera się obecnie na algorytmie wyboru kolejnych grup leków przeciwzapalnych, w zależności od uzyskanego efektu terapeutycznego. Glikokortykosteroidy, które dają szybki i silny efekt przeciwzapalny, są zwykle lekami pierwszego wyboru. Gdy stan zapalny nawraca przy dawce prednizonu mniejszej niż $10 \mathrm{mg} / 24 \mathrm{~h}$, przechodzi się na terapię immunosupresyjną.

Wybór leku immunosupresyjnego zależy od rodzaju i ciężkości NZBN oraz od stanu ogólnego i wieku pacjenta. Leki trzeciego wyboru mają działanie immunomodulujące, są to przeciwciała przeciw cytokinom lub pochodne interferonów. Pierwszym lekiem immunomodulującym zatwierdzonym do terapii NZBN (2016 r., USA) jest przeciwciało przeciwko czynnikowi martwicy guza $\alpha$ (anty-TNF- $\alpha$ ) - adalimumab. W Polsce w 2019 r. Ministerstwo Zdrowia wprowadziło refundację adalimumabu (Humira, Abbvie), w ramach programu lekowego, do terapii nieinfekcyjnego zapalenia pośredniej i tylnej części błony naczyniowej oraz całej błony naczyniowej u dorosłych. Należy podkreślić, że izolowane nieinfekcyjne zapalenie tęczówki i ciała rzęskowego nie jest objęte programem lekowym.

Czynnik martwicy guza $\alpha$ to cytokina produkowana głównie przez monocyty, występująca we krwi zdrowego człowieka w stężeniu poniżej $16 \mathrm{pg} / \mathrm{ml}$. Obserwuje się wzrost jej stężenia we krwi osób chorujących na astmę, chorobę Leśniowskiego-Crohna i choroby nowotworowe [1]. Większe stężenia TNF- $\alpha$ wykryto w płynie komorowym pacjentów z zapaleniami błony naczyniowej [1]. Czynnik martwicy guza $\alpha$ wraz z innymi cytokinami, także indukowanymi przez siebie, oddziałuje na monocyty, makrofagi, fibroblasty, neutrofile i komórki tuczne. Wzmaga proliferację i różnicowanie limfocytów T i B, indukuje syntezę IL-1 i zwiększa jej ekspresję na powierzchni komórek, a także wpływa na zdolność komórek śródbłonka do adhezji limfocytów, stąd jego wielokierunkowy udział w NZBN. TNF- $\alpha$ wiąże się z dwoma rodzajami receptorów: rozpuszczalnym receptorem TNFR-1, który bierze udział w aktywacji apoptozy i procesów zapalnych, oraz receptorem błonowym TNFR-2, który odgrywa rolę w regulacji wzrostu i proliferacji komórki. Obecność obu receptorów wykazano w ciele szklistym, tęczówce, ciele rzęskowym i w tylnej części naczyniówki [2].

Adalimumab to przeciwciało monoklonalne IgG1k, blokujące interakcje TNF- $\alpha$ z receptorem rozpuszczalnym i błonowym [1]. W 2002 r. został zatwierdzony przez Agencję ds. Żywności i Leków (FDA, Food \& Drug Administration) do terapii reumatoidalnego zapalenia stawów i od tamtej pory jest stosowany w leczeniu młodzieńczego idiopatycznego zapalenia stawów, zesztywniającego zapalenia stawów kręgosłupa, choroby Leśniowskiego-Crohna, wrzodziejącego zapalenia jelit, łuszczycowego zapalenia stawów i łuszczycy. W 2016 r. w Stanach Zjednoczonych, a w 2019 r. w Polsce zatwierdzono adalimumab do terapii nieinfekcyjnych ZBN części pośredniej, tylnej oraz zapalenia całej błony naczyniowej tylko u dorosłych pacjentów, mimo że istnieją doniesienia o skuteczności adalimumabu w NZBN u dzieci $[1,3]$.

Adalimumab jest podawany podskórnie. Jego czas półtrwania to 15-19 dni, jest więc zwykle stosowany co 14 dni, po początkowej dawce wysycającej $80 \mathrm{mg}$, a następnie w dawce $40 \mathrm{mg}$, u dorosłych i dzieci ważących więcej niż $30 \mathrm{~kg}$. U dzieci ważących mniej niż $30 \mathrm{~kg}$ stosuje się dawkę $20 \mathrm{mg}$ lub $24 \mathrm{mg} / \mathrm{m}^{2}$.

\section{WSKAZANIA DO TERAPII ADALIMUMABEM}

\section{Nieinfekcyjne zapalenie części pośredniej błony naczyniowej u dorosłych}

Do terapii adalimumabem powinni być kierowani pacjenci z ciężkim nieinfekcyjnym zapaleniem części pośredniej błony naczyniowej, któremu często towarzyszy obrzęk tor- 
bielowaty plamki. Należy pamiętać o wykluczeniu innych przyczyn przetrwałego obrzęku plamki: trakcji ze strony ciała szklistego, neowaskularyzacji podplamkowej i zwyrodnienia barwnikowego siatkówki. Przewlekły przebieg, z kumulacyjnym charakterem uszkodzenia funkcji wzro$\mathrm{ku}$, występuje $\mathrm{u}$ młodych dorosłych $\mathrm{z}$ NZBN związanym z młodzieńczym zapaleniem stawów oraz w nietypowych, bo przewlekłych, obustronnych postaciach NZBN na tle autoagresji z towarzyszącym haplotypem HLA-B27 [4, 5]. W przewlekłym zapaleniu części pośredniej błony naczyniowej przed przystąpieniem do terapii anty-TNF- $\alpha$, poza wykluczeniem towarzyszących chorób infekcyjnych, należy bezwzględnie wyeliminować współistnienie predyspozycji do chorób demielinizacyjnych, ze względu na ryzyko rozwoju stwardnienia rozsianego.

\section{Choroba Behçeta}

Choroba Behçeta, którą charakteryzują: przewlekłe zapalenie żył siatkówki, obrzęk torbielowaty plamki i epizody obustronnego ostrego zapalenia tęczówki przy współistniejącym HLA-B51, jest coraz częściej rozpoznawana w polskiej populacji. Ze względu na ryzyko powikłań zakrzepowych wynikające z uszkodzenia ściany naczyń żylnych konieczne jest wczesne konsekwentne zwalczanie zapalenia, często we współpracy z reumatologiem, przy towarzyszących objawach ogólnoustrojowych. Skuteczność adalimumabu w leczeniu ocznej postaci choroby Behçeta była przedmiotem badania Bawazeera i wsp. [7]. Badanie dotyczyło 21 oczu 11 pacjentów płci męskiej. Okres obserwacji wyniósł średnio 10,8 miesiąca, a średni wiek pacjentów - 28 lat. Jedynie w przypadku czworga oczu nie uzyskano poprawy ostrości widzenia (dwoje z nich cechowało się bliznami w polu plamkowym, dwoje innych należało do tego samego, niereagującego na terapię pacjenta). Pozostałe 81\% oczu wykazało poprawę o 3 lub więcej rzędów w tablicach Snellena. U 10 pacjentów zaobserwowano całkowite wyciszenie stanu zapalnego po średnio 4 tygodniach terapii, co pozwoliło na redukcję podtrzymującej dawki glikokortykosteroidów. Wieloośrodkowe, retrospektywne badania dotyczące 44 pacjentów (66 oczu) z NZBN leczonych adalimumabem w przebiegu choroby Behçeta wykazało poprawę we wszystkich analizowanych parametrach: liczbie nawrotów, ostrości wzroku, centralnej grubości siatkówki w polu plamkowym w optycznej koherentnej tomografii [8].

\section{Choroidopatia birdshot}

Choroidopatia typu birdshot występuje głównie u kobiet. Patognomiczny dla niej jest haplotyp HLA-A29, charakterystyczne są: obustronne, głębokie, rozsiane, niewielkie ogniska nacieków naczyniówki, nawracający obrzęk torbielowaty plamki, wysięk w ciele szklistym. Choroba prowadzi do makulopatii i neuropatii nerwu wzrokowego. Nie stwierdza się związku z innymi chorobami autoimmunologicznymi. Ze względu na przewlekły, postępujący charakter choroby często stosowane jest leczenie immunosupresyjne, które nie zawsze prowadzi do pełnego wyciszenia stanu zapalnego. Efektywność adalimumabu w choroidopatii birdshot była obserwowana u części pacjentów stosujących jednocześnie glikokortykosteroidy i immunosupresję - odnotowano zmniejszenie centralnej grubości siatkówki i poprawę ostrości wzroku [9].

\section{Zapalenie współczulne}

Zapalenie współczulne to jedno z najcięższych zapaleń autoimmunologicznych błony naczyniowej obojga oczu, występujące u 0,2-0,5\% pacjentów po urazie oka, a w 0,01\% przypadków po zabiegu operacyjnym [1]. Ma charakter ziarninujący, przewlekły, nawracający, może dotyczyć wszystkich części błony naczyniowej i wiąże się z dużym ryzykiem całkowitej utraty wzroku. Zapalenie współczulne wymaga zwykle przewlekłej glikokortykosteroidoterapii ogólnej i immunosupresji, w redukcji jego nawrotów opisano skuteczność adalimumabu [10].

\section{Sarkoidoza}

Sarkoidoza może wywołać ziarninujące zapalenie wszystkich części błony naczyniowej i przewlekłe zapalenie żył siatkówki, często z towarzyszącym obrzękiem torbielowatym plamki. Oczne manifestacje sarkoidozy są do tej pory zwykle leczone miejscowo, okołogałkowo i ogólnie glikokortykosteroidami. Pulmonolodzy stosują w sarkoidozie płucnej przewlekłą glikokortykosteroidoterapię, rzadko decydują się na wdrożenie immunosupresji. Jeśli nie ma wskazań pulmonologicznych do terapii ogólnej, to okulista decyduje o wyborze odpowiedniego leczenia.

Pojawiły się prace o efektywności adalimumabu w zapobieganiu nawrotów NZBN na tle sarkoidozy [11]. W prospektywnym badaniu przeprowadzonym przez Erckensa i wsp. poddano analizie działanie adalimumabu u 26 pacjentów z opornym na leczenie zapaleniem tylnego odcinka błony naczyniowej wtórnym do sarkoidozy, niereagującym na terapię prednizonem i/lub metotreksatem oraz wykazujących brak tolerancji powyższych terapii ze względu na działania niepożądane. Wśród badanych wyjściowo 13 (31\%) prezentowało zapalenie tarczy nerwu wzrokowego, które po terapii adalimumabem ustąpiło całkowicie w przypadku 11 oczu i częściowo w przypadku dwojga oczu. Torbielowaty obrzęk plamki (CME, cystoid macular edema), wykazany w badaniu angiografii fluoresceinowej lub optycznej koherentnej tomografii na początku badania w 12 oczu (28,6\%), ustąpił całkowicie w ośmiorgu oczu i częściowo w pozostałych czworgu. W 25 oczu $(59,5 \%)$ z zapaleniem naczyniówki - u 17 nastąpiła zupełna, a u ośmiorga częściowa poprawa. W przypadku dwojga oczu (4,8\%) zaobserwowano ustąpienie cech zapalenia żył 
siatkówki. W dziewięciorgu oczach $(21,4 \%)$ z zapaleniem ciała szklistego u wszystkich nastąpiła poprawa o co najmniej 2 stopnie w zaproponowanej przez SUN skali oceny wysięku w komorze ciała szklistego. Średnia dawka glikokortykosteroidów stosowana przez badanych pacjentów - 15,6-10,7 mg/24 h - mogła zostać zredukowana do 3,6-5,0 mg/24 h. Dawka metotreksatu spadła z początkowych 9,6-5,5 mg/tydzień do 5,6-4,1 mg/tydzień przy ukończeniu badania $(\mathrm{p}<0,05)$.

\section{ZASTOSOWANIE ADALIMUMABU POZA WSKAZANIAMI PROGRAMU LEKOWEGO}

\section{0stre zapalenia tęczówki na tle autoagresji}

Terapia ostrych, nieziarninujących, jednostronnych zapaleń tęczówki, które są klasycznymi manifestacjami autoagresji, opiera się zwykle na doraźnym leczeniu miejscowym i okołogałkowym, a przy dużej częstotliwości nawrotów z towarzyszącymi powikłaniami takimi jak rozwój jaskry glikokortykosteroidozależnej wprowadza się immunosupresję, najlepiej lekami zmniejszającymi namnażanie limfocytów. Przy braku efektu terapeutycznego w nawracającym zapaleniu przedniego odcinka błony naczyniowej z autoagresji istnieje szansa na terapię biologiczną ze wskazań reumatologicznych. Analizowano wpływ terapii anty-TNF- $\alpha$ na przebieg zapalenia tęczówki u 143 pacjentów z zesztywniającym zapaleniem stawów kręgosłupa, wykazując w rocznej obserwacji remisję zapalenia u $80 \%$ chorych [6]. Każdego pacjenta z NZBN z towarzyszącym HLA-B27 należy skierować do konsultacji reumatologicznej z ewentualnym badaniem rezonansu magnetycznego stawów krzyżowo-biodrowych. Przy braku wskazań ogólnoustrojowych do terapii adalimumabem ciężkie ostre zapalenia tęczówki bez towarzyszącego obrzęku plamki mogą być leczone przez okulistę off label.

\section{Przewlekłe zapalenia tęczówki i ciała rzęskowego u dzieci}

Niestety, mimo licznych badań dokumentujących skuteczność adalimumabu w przewlekłym zapaleniu tęczówki i ciała rzęskowego u dzieci na tle młodzieńczego zapalenia stawów jego stosowanie do 18. r.ż. pacjenta może być prowadzone off label po uzyskaniu zgody rodziców i nie jest refundowane ze wskazań okulistycznych. U dzieci leczonych adalimumabem ze wskazań reumatologicznych obserwowano znaczące zmniejszenie nasilenia NZBN [12]. Ze względu na poważne ryzyko trwałego upośledzenia ostrości wzroku w tej grupie pacjentów, w tym: rozwoju jaskry wtórnej, makulopatii wynikającej z przetrwałego obrzęku plamki, zaniku gałki ocznej na skutek niewydolności ciała rzęskowego, okulista powinien współpracować $\mathrm{z}$ reumatologiem, określać wskazania okulistyczne do terapii immunosupresyjnej i biologicznej. Należy podkreślić, że efektu terapeutycznego w NZBN nie wykazuje etanercept, białko fuzyjne, inhibitor TNF- $\alpha$ często stosowany ze wskazań reumatologicznych w młodzieńczym zapaleniu stawów u dzieci.

\section{KWALIFIKACJA DO TERAPII ADALIMUMABEM}

Przed włączeniem leczenia adalimumabem konieczne jest wykonanie badań laboratoryjnych, obrazowych i konsultacji, jak pokazano w tabeli 1 [18]. Poza konsultacją neurologiczną zaleca się rezonans magnetyczny mózgowia z kontrastem w kierunku ognisk demielinizacji i wykonanie wzrokowych potencjałów wywołanych z oceną latencji fali P100.

\section{TABELA}

Badania przy kwalifikacji do leczenia adalimumabem [18].

a) morfologia krwi obwodowej lub morfologia krwi obwodowej z rozmazem

\begin{tabular}{|c|c|}
\hline b) & płytki krwi (PLT) \\
\hline c) & odczyn Biernackiego (OB) \\
\hline d) & aminotransferaza alaninowa (AIAT) \\
\hline e) & aminotransferaza asparaginianowa (AspAT) \\
\hline f) & poziom kreatyniny w surowicy \\
\hline g) & białko C-reaktywne \\
\hline h) & badanie ogólne moczu (do decyzji lekarza) \\
\hline i) & próba tuberkulinowa lub test Quantiferon \\
\hline j) & test na kiłę \\
\hline k) & test na boreliozę \\
\hline I) & obecność antygenu HBs \\
\hline m) & przeciwciała anty-HCV \\
\hline n) & obecność antygenu wirusa HIV (HIV Ag/Ab Combo) \\
\hline o) & stężenie elektrolitów w surowicy \\
\hline p) & $\begin{array}{l}\text { RTG klatki piersiowej z opisem (do } 6 \text { miesięcy przed } \\
\text { kwalifikacją) }\end{array}$ \\
\hline q) & EKG z opisem \\
\hline r) & $\begin{array}{l}\text { konsultacja neurologiczna z ewentualnym badaniem MRI } \\
\text { (do decyzji lekarza konsultującego) }\end{array}$ \\
\hline s) & konsultacja ginekologiczna z wykluczeniem ciąży \\
\hline t) & $\begin{array}{l}\text { ocena stopnia nacieków komórkowych w komorze } \\
\text { przedniej oka oraz stopnia przymglenia ciała szklistego } \\
\text { według kryteriów SUN }\end{array}$ \\
\hline u) & $\begin{array}{l}\text { badanie okulistyczne z oceną najlepszej skorygowanej } \\
\text { ostrości wzroku na tablicach Snellena lub ETDRS, } \\
\text { pomiarem ciśnienia wewnątrzgałkowego, oceną dna oka } \\
\text { i plamki żółtej w badaniu optycznej koherentnej tomografii } \\
\text { (OCT), ocena gałki ocznej w badaniu ultrasonograficznym } \\
\text { typu B. }\end{array}$ \\
\hline
\end{tabular}

Przed leczeniem, w jego trakcie i przez 4 miesiące po odstawieniu leku pacjenta należy monitorować pod kątem wystąpienia zakażeń, w tym gruźlicy. Należy poinformować pacjenta, aby unikał podróży w rejony o dużym ryzyku zachorowania na gruźlicę lub występujących endemicznie 
grzybic takich jak: histoplazmoza, kokcydioidomykoza, blastomykoza. Jeśli u pacjenta wystąpi nowe poważne zakażenie lub posocznica, podawanie adalimumabu należy wstrzymać do czasu opanowania zakażenia. Należy zachować ostrożność u osób z nawracającymi zakażeniami w wywiadzie lub z chorobami, które mogą zwiększać skłonność do zakażeń, a także w przypadku stosowania w skojarzeniu z lekami immunosupresyjnymi. Przed planowanym zabiegiem chirurgicznym należy odstawić lek na miesiąc i zachować wzmożoną obserwację pooperacyjną.

W trakcie leczenia adalimumabem nie powinno się stosować szczepionek zawierających żywe drobnoustroje.

\section{Działania niepożądane}

Bezpieczeństwo i efektywność adalimumabu w terapii NZBN oceniano w wieloośrodkowym, międzynarodowym badaniu klinicznym VISUAL, którego pierwsza faza wykazała skuteczność adalimumabu w aktywnym NZBN, pozwalającą na redukcję lub odstawienie glikokortykosteroidów, w drugiej fazie potwierdzono efektywność adalimumabu w zapobieganiu nawrotom NZBN, a w trzeciej fazie oceniano wyniki długotrwałej terapii $[3,13,14]$.

Najczęstszymi działaniami niepożądanymi adalimumabu są miejscowa reakcja związana z iniekcją oraz reakcja alergiczna $[3,13]$. W badaniu VISUAL I $(\mathrm{n}=111)$ odnotowano 18 przypadków poważnych działań niepożądanych. Wśród nich wyróżniono dwa przypadki nowotworów (rakowiak przewodu pokarmowego, glejak wielopostaciowy) i po jednym przypadku aktywacji latentnej gruźlicy, reakcji toczniopodobnej i demielinizacji [3]. W badaniu VISUAL II $(\mathrm{n}=15)$ $\mathrm{w}$ grupie leczonej adalimumabem wystąpił jeden przypadek nowotworu (rak kolczystokomórkowy skóry) i trzy przypadki uaktywnienia latentnej gruźlicy [13]. W badaniu VISUAL III ( $n=424)$ w przypadku 82 pacjentów doszło do zaprzestania terapii adalimumabem ze względu na działania niepożądane. Stwierdzono: jeden przypadek aktywnej postaci gruźlicy, pięć przypadków zakażeń oportunistycznych, 48 poważnych infekcji i 12 nowotworów. U pięciu pacjentów zdiagnozowano zaburzenia demielinizacyjne, wraz ze stwardnieniem rozsianym [14]. W badaniach porównujących tolerancję adalimumabu i infliksymabu, który jest lekiem anty-TNF- $\alpha$ podawanym dożylnie, nie wykazano znacznych różnic w częstości występowania działań niepożądanych $[15,16]$.

Szczególnej uwagi wymaga ryzyko pierwotnego zakażenia prątkiem gruźlicy lub reaktywacji gruźlicy w trakcie terapii inhibitorami TNF- $\alpha$, bowiem zaburzają one aktywację makrofagów i tworzenie gruzełka gruźliczego. Monitorowanie pacjenta $\mathrm{w}$ trakcie terapii nie może opierać się jedynie na wykonywaniu zdjęć rentgenowskich klatki piersiowej, gdyż w 53\% przypadków obserwowano pozapłucne postacie gruźlicy [17].

Ze względu na obserwowane przypadki chorób nowotworowych w grupie pacjentów leczonych adalimumabem, przed rozpoczęciem leczenia oraz w jego trakcie należy wykonywać badania na obecność raka skóry niebędącego czerniakiem, szczególnie u pacjentów poddanych intensywnemu leczeniu immunosupresyjnemu oraz u pacjentów z łuszczycą leczonych w przeszłości metodą PUVA. Lek należy stosować ostrożnie u pacjentów z przewlekłą obturacyjną chorobą płuc oraz u osób palących nałogowo, ze względu na zwiększone ryzyko wystąpienia nowotworu złośliwego płuc i nosogardła [17]. Osoby z wrzodziejącym zapaleniem jelita grubego i ze zwiększonym ryzykiem dysplazji lub raka jelita grubego należy poddawać okresowym badaniom endoskopowym. Obowiązkowe jest monitorowanie morfologii z rozmazem, ponieważ $\mathrm{w}$ trakcie terapii anty-TNF- $\alpha$ może dojść do pancytopenii i małopłytkowości. Przy wizytach kontrolnych poza okresowymi badaniami laboratoryjnymi konieczne jest zwrócenie uwagi na ogólnoustrojowe objawy kliniczne i dokładny wywiad w kierunku osłabienia, krwawień i podwyższonej temperatury ciała.

Do bezwzględnych przeciwwskazań należą: nadwrażliwość na którykolwiek składnik preparatu, czynna gruźlica lub inne ciężkie zakażenie, posocznica albo zakażenia drobnoustrojami oportunistycznymi oraz niewydolność serca klasy III lub IV według NYHA (New York Heart Association) [18].

\section{PODSUMOWANIE}

Wprowadzenie terapii immunomodulujących spowodowało przełom w reumatologii, pozwala na poprawę skuteczności leczenia, rokowania i jakości życia pacjentów. W okulistyce mamy nareszcie szansę na włączenie pacjenta do programu terapeutycznego $\mathrm{z}$ wykorzystaniem adalimumabu, co stwarza dla chorych duże nadzieje, a od lekarzy prowadzących wymaga rzetelnej diagnostyki i odpowiedzialności.

\author{
ADRES DO KORESPONDENCJ \\ lek. Julia Kręcicka \\ Klinika Okulistyki, \\ Uniwersytecki Szpital Kliniczny \\ im. Jana Mikulicza-Radeckiego we Wrocławiu \\ 50-556 Wrocław, ul. Borowska 213 \\ e-mail: julia.krecicka@gmail.com
}

\section{ORCID}

Julia Kręcicka - ID - http://orcid.org/0000-0003-3895-3096

Anna Turno-Kręcicka - ID - http://orcid.org/0000-0001-6732-1851

Marta Misiuk-Hojło - ID - http://orcid.org/0000-0002-4020-3203 


\section{Piśmiennictwo}

1. LaMattina KC, Goldstein DA. Adalimumab for the treatment of uveitis, Expert Rev Clin Immunol. 2017; 13(3): 181-8.

2. Sippy BD, Hofman FM, Wright $A D$ et al. Soluble tumor necrosis factor receptors are present in human vitreous and shed by retinal pigment epithelial cells. Exp Eye Res. 1996; 63(3): 311-7.

3. Jaffe GJ, Dick AD, Brézin AP et al. Adalimumab in patients with active noninfectious uveitis. N Engl J Med. 2016; 375(10): 932-43.

4. Rudwaleit $M$, Rodevand $E$, Holck $P$ et al. Adalimumab effectively reduces the rate of anterior uveitis flares in patients with active ankylosing spondylitis: results of a prospective open-label study. Ann Rheum Dis. 2009; 68(5): 696-701.

5. Van Denderen JC, Visman IM, Nurmohamed MT et al. Adalimumab significantly reduces the recurrence rate of anterior uveitis in patients with ankylosing spondylitis. J Rheumatol. 2014; 41(9): 1843-8.

6. Kim M, Won JY, Choi SY et al. Anti-TNF-a Treatment for HLA-B27-Positive Ankylosing Spondylitis-Related Uveitis. Am J Ophthal. 2016; 170: 32-40.

7. Bawazeer A, Raffa LH, Nizamuddin SH. Clinical experience with adalimumab in the treatment of ocular Behçet disease. Ocul Immunol Inflamm. 2010; 18(3): 226-32.

8. Fabiani C, Vitale A, Emmi G et al. Efficacy and safety of adalimumab in Behçet's disease-related uveitis: a multicenter retrospective observational study. Clin Rheumatol. 2017; 36(1): 183-9.

9. Steeples LR, Spry P, Lee RWJ et al. Adalimumab in refractory cystoid macular edema associated with birdshot chorioretinopathy. International Ophthalmology. 2018; 38(3): 1357-62.

10. Hiyama T, Harada Y, Kiuchi Y. Effective treatment of refractory sympathetic ophthalmia with glaucoma using adalimumab. Am J Ophthalmol Case Rep. 2019; 14: 1-4.

11. Erckens RJ, Mostard RL, Wijnen PA et al. Adalimumab successful in sarcoidosis patients with refractory chronic non-infectious uveitis. Graefes Arch Clin Exp Ophthalmol. 2012; 250(5): 713-20.

12. Castiblanco C, Meese H, Foster CS. Treatment of pediatric uveitis with adalimumab: the MERSI experience. J Aapos. 2016; 20(2): 145-7.

13. Nguyen QD, Merrill PT, Jaffe GJ et al. Adalimumab for prevention of uveitic flare in patients with active non-infectious uveitis controlled by cortiocosteroids (VISUAL II): a multicenter, double-masked, randomized, placebo-controlled phase 3 trial. Lancet. 2016; 388: 1183-92.

14. Suhler EB, Adán A, Brézin AP et al. Safety and efficacy of adalimumab in patients with noninfectious uveitis in an ongoing open-label study: VISUAL III. Ophthalmology. 2018; 125: 1075-87.

15. Vallet $H$, Seve $P$, Biard $L$ et al. Infliximab versus adalimumab in the treatment of refractory inflammatory uveitis: a multicenter study from the French uveitis network. Arthritis Rheumatol. 2016; 68: 1522-30.

16. Fabiani C, Vitale A, Rigante D et al. Comparative efficacy between adalimumab and infliximab in the treatment of non-infectious intermediate uveitis, posterior uveitis, and panuveitis: a retrospective observational study of 107 patients. Clin Rheumatol. 2019; 38: 407-15.

17. Rosenbaum JT, Bodaghi B, Couto $C$ et al. New observations and emerging ideas in diagnosis and management of non-infectious uveitis: A review. Semin Arthritis Rheum. 2019; 49(3): 438-45.

18. Załącznik B.105. Leczenie zapalenia błony naczyniowej oka (ZBN) - część pośrednia, odcinek tylny lub cała błona naczyniowa (ICD-10 H 20.0, H 30.0). https://www.nfz.gov.pl.

Wkład autorów:

Anna Turno-Kręcicka: sprawdzenie danych, weryfikacja;

Marta Misiuk-Hojło: ostateczna akceptacja;

Julia Kręcicka: przygotowanie manuskryptu.

Konflikt interesów:

Nie występuje.

Finansowanie:

Nie występuje.

Etyka:

Treści przedstawione w artykule są zgodne z zasadami Deklaracji Helsińskiej,

dyrektywami EU oraz ujednoliconymi wymaganiami dla czasopism biomedycznych.
Authors' contributions:

Anna Turno-Kręcicka: checking and verifying the data;

Marta Misiuk-Hojło: accepting final version of the manuscript;

Julia Kręcicka: preparing manuscript.

Conflict of interest:

None.

Financial support:

None.

Ethics:

The content presented in the article complies with the principles of the Helsinki

Declaration, EU directives and harmonized requirements for biomedical journals. 